\title{
RANCANG BANGUN APLIKASI PENJUALAN DAN PEMBELIAN BARANG PADA KOPERASI KARTIKA SAMARA GRAWIRA PRABUMULIH
}

\author{
Ana Naela Nurhayati ${ }^{1}$, Ahmat Josi ${ }^{2}$, Nur Aini Hutagalung ${ }^{3}$ \\ Fakultas Komputerisasi Akuntansi, Perguruan Tinggi STMIK Prabumulih \\ ananaela_nurhayati@yahoo.com ${ }^{1}$,ahmat_josi@yahoo.com ${ }^{2}$, \\ ainihutagalung@yahoo.com ${ }^{3}$
}

\begin{abstract}
ABSTRAK
Perkembangan teknologi informasi saat ini sudah berkembang dengan cepat dan sudah banyak keuntungan yang dirasakan contohnya dalam bidang bisnis. walaupun perkembangan teknologi sudah berkembang dengan cepat, tapi masih banyaknya perusahaan ataupun badan usaha yang belum bisa memanfaatkannya seperti Koperasi Kartika Samara Grawira adalah salah satu badan koperasi yang bergerak dalam bidang usaha. Dalam transaksi sehari-hari Koperasi Kartika Samara Grawira masih menggunakan pencatatan data dan pembuatan laporan menggunakan Microsoft Excel dan Microsoft Word. Dengan cara pengolahaan data seperti itu masih sering terjadi kekeliruan pada saat melakukan pembukuan dan pembuatan laporan bahkan masih sangat membutuhkan waktu yang cukup lama. Tujuan penelitian ini adalah ingin mengetahui alur sistem transaksi penjualan dan pembelian yang sedang berjalan di Koperasi Kartika Samara Grawira untuk dapat merancang dan membuat sistem transaksi penjualan dan pembelian barang berbasis web, sehingga pengolahan data dapat di lakukan secara terkomputer untuk mempermudah dan mempercepat proses transaksi, memudahkan pencarian data, memudahkan pembuatan laporan dan meminimalisir kesalahan yang akan terjadi. Metodelogi yang digunakan adalah studi kepustakaan, penelitian langsung terhadap objek yang ditelitidan wawancara.
\end{abstract}

Kata Kunci : Koperasi, Penjualan, Pembelian, Barang.

\section{PENDAHULUAN}

\subsection{Latar Belakang}

Perkembangan teknologi informasi saat ini berjalan dengan cepat dan banyak sekali keuntungan yang bisa didapatkan dari perkembangan teknologi informasi. Sebagai contohnya di bidang bisnis, teknologi informasi dapat digunakan untuk meningkatkan promosi maupun untuk membantu pengolahan data-data yang ada untuk dijadikan sebuah informasi. Untuk pengolahan data menjadi informasi salah satu contohnya adalah pengolahan data atau transaksi sebuah pembelian maupun penjualan, dimana dengan diolahnya data menggunakan komputer maka proses pengolahanya akan menjadi lebih cepat dan hasilnnya jauh lebih baik dari pada dikerjakan tanpa menggunakan komputer (Rumanta,2013:44-49).

Penggunan komputer dalam koperasi sangat membantu dalam melakukan transaksi menjadi cepat dan tepat waktu saat mengumpulkan data-data yang diperlukan, salah satu informasi penting yang dihasilkan adalah informasi transaksi penjualan dan pembelian barang. Dalam koperasi, informasi penjualan dan pembelian dibuat untuk 
mempermudah Pimpinan, Sekertaris, Bendahara dan Pegawai dalam mengontrol pengolahan data penjualan dan pembelian barang (Fatkhudin,2016:23-36). Pengolahan data yang tepat akan menghasilkan keuntungan, tetapi jika pengolahan datanya masih dilakukan secara manual, terkadang hasil yang diperolehpun tidak memuaskan karena suatu hal yaitu kemampuan manusia dan olah pikir yang terbatas (Hartini and Sarjono,2016:30-34).

Koperasi Kartika Samara Grawira adalah salah satu badan koperasi yang bergerak dalam bidang usaha. Dalam transaksi sehari-hari Koperasi Kartika Samara Grawira masih menggunakan pencatatan data dan pembuatan laporan menggunakan Microsoft Excel dan Microsoft Word. Dengan cara pengolahaan data seperti itu masih sering terjadi kekeliruan pada saat melakukan pembukuan dan pembuatan laporan bahkan masih sangat membutuhkan waktu yang cukup lama. Tujuan penelitian ini adalah ingin mengetahui alur sistem transaksi penjualan dan pembelian yang sedang berjalan di Koperasi Kartika Samara Grawira untuk dapat merancang dan membuat sistem transaksi penjualan dan pembelian barang berbasis web, sehingga pengolahan data dapat di lakukan secara Online untuk mempermudah dan mempercepat proses transaksi, memudahkan pencarian data, memudahkan pembuatan laporan dan meminimalisir kesalahan yang akan terjadi.

Berdasarkan latar belakang tersebut diatas maka Penulis mengambil judul "Rancang Bangun Aplikasi Penjualan dan Pembelian Barang pada Koperasi Kartika Samara Grawira Prabumulih ”.

\subsection{Rumusan Masalah}

Berdasarkan latar belakang di atas, maka permasalahan yang di ambil adalah "Bagaimana Merancang dan Membangun Aplikasi Penjualan dan Pembelian Barang pada Koperasi Kartika Samara Grawira Prabumulih Berbasis Web ?’.

\subsection{Batasan Masalah}

Agar tidak menyimpang dari topik permasalahan maka perlu adanya batasan masalah, sebagai berikut :

1. Penelitian ini hanya sebatas perancangan aplikasi penjualan dan pembelian barang pada Koperasi Kartika Samara Grawira Prabumulih.

2. Pada aplikasi ini dibangun dengan menggunakan Bahasa Pemrograman PHP ( Hypertext Prepocessor) dan Database MySQL.

3. Penjualan dan pembelian pada Koperasi Kartika Samara Grawira Prabumulih seperti penjualan Setelan PDL dan PDH, Tas Loreng, Tas Persit, Topi, Sepatu PDH dan PDL, wedges Persit, Jaket Loreng, Kaos loreng, Jas Hujan Loreng, Sweater Loreng.

4. Aplikasi ini tidak mengadakan Diskon Pembelian Barang.

5. Proses pembelian bisa kirim via Transfer ATM BRI, Atm MANDIRI dan bisa langsung kekoperasi untuk wilayah Kota Prabumulih.

6. Dapat melayani pengiriman barang menggunakan jasa kirim JNE saja.

\subsection{Tujuan dan Manfaat Penelitian}

\subsubsection{Tujuan Penelitian}

Adapun tujuan dari penelitian ini adalah sebagai Berikut :

1. Untuk membuat website pengolahan data penjualan dan pembelian. 
2. Dapat mengetahui sisa barang dagang yang telah terjual.

3. Membangun website penjualan dan pembelian di Koperasi Kartika Samara Grawira Prabumulih.

\subsubsection{Manfaat Penelitian}

Dengan adanya aplikasi pengolahan data Penjualan dan Pembelian Barang diharapkan dapat memberi manfaat. adapun manfaatnya sebagai berikut :

\subsubsection{Manfaat Penelitian bagi Koperasi Kartika Samara Grawira :}

1. Dapat mempermudah proses pengolahan data penjualan dan pembelian barang pada

Koperasi Kartika Samara Grawira Prabumulih.

2. Dapat menjual produk yang ada di Koperasi Kartika Samara Grawira Prabumulih secara lebih luas.

3. Dapat mengikuti perkembangan teknologi dengan cara terus selalu mengembangkan sistem yang lebih baik untuk melakukan setiap transaksi jual beli barang.

\subsubsection{Manfaat Penelitian bagi Penulis}

1. Penulis dapat memahami secara langsung bagaimana proses penjualan dan pembelian barang di Koperasi Kartika Samara Grawira Prabumulih.

2. Memberikan solusi untuk mempermudah melakukan transaksi jual beli barang di Koperasi Kartika Samara Grawira Prabumulih.

3. Dapat memahami Bahasa Pemrograman PHP (Hypertext Prepocessor) dan $X A M P P$ dengan format database MySQL penelitian ini dapat juga di jadikan sebagai media latihan untuk penulisan sebelum memasuki dunia kerja yang sesungguhnya.

4. Penulis dapat menciptakan aplikasi rancang bangun penjualan dan pembelian barang pada Koperasi Kartika Samara Grawira Prabumulih.

\section{KAJIAN PUSTAKA}

\subsection{Pengertian Rancang Bangun}

Rancang bangun adalah kegiatan menerjemahkan hasil analisa ke dalam bentuk paket perangkat lunak kemudian menciptakan sistem tersebut ataupun memperbaiki sistem yang sudah ada (Zulfiandri,2014:474). Rancang Bangun adalah penggambaran, perencanaan, dan pembuatan sketsa atau pengaturan dari beberapa elemen yang terpisah kedalam suatu kesatuan yang utuh dan berfungsi (Hasyim,dkk,2014:2).

Dari pengertian diatas Penulis menyimpulkan bahwa Rancang Bangun adalah tahap awal dari membuat gambaran dan bentuk sketsa yang belum pernah dibuat sama sekali lalu dikelolah menjadi gambaran atau sketsa yang memiliki fungsi yang diinginkan.

\subsection{Pengertian Aplikasi}

Aplikasi adalah salah satu unit perangkat lunak yang dibuat untuk melayani kebutuhan akan beberapa aktivitas (Supadi,2015:4). Aplikasi adalah program yang berisikan perintah-perintah untuk melakukan pengolahan data dengan membuat sistem 
atau program agar data diolah. misalnya Microsoft Word dan Microsoft Excel (Maulana and Bunyamin,2015:2).

Dari pengertian diatas Penulis menyimpulkan bahwa aplikasi adalah program siap pakai untuk melayani kebutuhan pengguna dalam berbagai aktifitas untuk pengolahan data.

\subsection{Pengertian Penjualan}

Penjualan adalah bagian dari kegiatan pemasaran yang memiliki makna yang luas yang meliputi berbagai fungsi perusahaan, pemasaran adalah sistem keseluruhan dari kegiatan usaha yang ditujukan untuk merencanakan, menentukan harga, memromosikan untuk dapat dipasarkan (Mega,2013:1). Penjualan adalah proses akhir dari kegiatan pemasaran, karena pada proses ini ada penetapan harga, serah terima barang dan adanya pembayaran yang disepakati oleh penjual dan pembeli (Hayuningtyas,2015:161).

Dari pengertian diatas Penulis menyimpulkan bahwa penjualan adalah sebuah proses yang dimana seseorang melakukan kegiatan pemasaran untuk memperoleh pendapatan dan dapat memenuhi kebutuhan pembeli.

\subsection{Pengertian Pembelian}

Pembelian adalah transaksi belanja untuk barang masuk atau pengeluaran uang yang kita lakukan untuk mendapatkan produk yang akan dijual, transaksi ini terjadi pada supplier yang produknya dibeli (Nugroho,2013:1). Pembelian adalah sebuah perusahaan dagang pembelian meliputi pembelian aktiva produktif, pembelian barang dagangan serta pembelian barang dan jasa lain dalam rangka kegiatan usaha (Hariyanto,2016:152).

Dari pengertian diatas Penulis menyimpulkan bahwa pembelian adalah suatu kegiatan yang mengeluarkan sejumlah uang untuk mendapatkan barang ataupun produk yang diinginkan sesuai dengan kebutuhan.

\subsection{Pengertian Barang}

Barang adalah segala sesuatu yang dapat ditawarkan konsumen baik berwujud maupun tidak berwujud yang diterima oleh pembeli agar dapat memuaskan keinginan atau kebutuhan konsumen (Riyono and Budiharja,2016:98). Barang adalah sekumpulan produk atau barang yang tersedia dalam jumlah dan jenis yang bermacam-macam untuk ditawarkan kepada konsumen (Agustina and Parjono,2017:43).

Dari pengertian diatas Penulis menyimpulkan bahwa barang adalah sesuatu barang atau produk yang ditawarkan dipasaran untuk dapat dimiliki, dipakai dan dikonsumsi oleh konsumen untuk memenuhi kebutuhannya.

\subsection{Pengertian Koperasi}

Koperasi adalah badan usaha yang mengorganisir pemanfaatan dan pendayagunaan sumber daya ekonomi para anggotanya atas dasar prinsip-prinsip koperasi dan kaidah usaha ekonomi untuk meningkatkan taraf hidup anggota pada khususnya dan masyarakat daerah kerja pada umumnya (Rudianto,2010:3). Koperasi adalah organisasi dari orang-orang yang berhimpun secara sukarela untuk memenuhi kebutuhan dan ekonomi, sosial dan budaya secara bersama-sama melalui kegiatan usaha yang dimiliki dan dikendalikan secara demokratis (Hendar,2010:2). 
Dari pengertian diatas Penulis menyimpulkan bahwa Koperasi adalah perkumpul suatu organisasi yang memanfaatkan sumber daya ekonomi untuk para anggotanya maupun masyarakat untuk memenuhi kebutuhan melalui transkasi di koperasi.

\subsection{Pengertian Website}

Website disebut Web adalah sebuah aplikasi web, karena melakukan action tertentu dan membantu anda melakukan kegiatan seperti membuka facebook, path, twitter dan lain-lain (TIM EMS,2014:1). Website adalah kumpulan halaman yang menampilkan informasi data teks, data gambar diam atau gerak, data animasi, suara, video atau gabungan dari semuanya yang baik untuk membentuk satu rangkaian bangunan yang saling terkait di mana masing-masing dihubungkan dengan jaringanjaringan halaman (Fathurrahman,2014:2)

Dari pengertian diatas Penulis menyimpulkan bahwa Website adalah sebuah aplikasi yang beisikan halaman tentang dokumen-dokumen ataupun informasi dalam bentuk text, gambar dan lain-lain dalam sebuah website.

\subsection{Pengertian PHP (Hypertext Preprocessor)}

PHP (Hypertext Preprocessor) adalah jenis bahasa scriptin (bahasa penerjemahan) seperti $H T M L$ yang lazim digunakan di halaman web, kode yang digunakan langsung dimasukkan ke dalam kode HTML (TIM EMS,2014:61). PHP (Hypertext Preprocessor) adalah bahasa skrip yang dapat ditanamkan atau disisipkan kedalam HTML (Sandi,2014:39).

Dari pengertian diatas Penulis menyimpulkan bahwa PHP (Hypertext Preprocessor) adalah Bahasa Pemrograman yang dirancang untuk membuat sebuah aplikasi web atau halaman web.

\subsection{Pengertian MySQL (My Structure Query Language)}

MySQL (My Structure Query Language) adalah sistem database populer paling lazim digunakan di PHP digunakan di lingkungan web, yang memiliki sifat scalable artinya bisa dipakai oleh program kecil hingga program besar (TIM EMS,2014:129).

MySQL (My Structure Query Language) adalah software RDBMS yang dapat mengolah database dengan cepat, dapat menampung data dalam jumlah sangat besar, dapat diakses oleh banyak user dan dapat melakukan suatu proses secara sinkron atau berbarengan(Raharjo,2015:16).

Dari pengertian diatas Penulis menyimpulkan bahwa $M y S Q L$ adalah database yang digunakan oleh Pemrograman aplikasi yang sama dengan PHP yang isinya kode untuk menjalankan aplikasi yang akan dibuat.

\subsection{Pengertian XAMPP}

$X A M P P$ adalah distribusi apache kecil dan ringan yang mengandung teknologi pengembangan web yang paling umum dalam satu paket (Sandi,2014:31). XAMPP adalah paket program web lengkap yang dapat anda pakai untuk belajar pemrograman web, khususnya $P H P$ dan $M y S Q L$ paket ini dapat di download secara gratis dan legal (Nugroho,2013:1).

Dari pengertian diatas Penulis menyimpulkan bahwa XAMPP adalah sebuah paket program untuk dapat mempelajari pemrograman web, khusus nya $P H P$ dan $M y S Q L$ dan paket programan ini mudah di dapatkan dengan cara di download secara gratis. 


\subsection{Pengertian Adobe Dreamweaver}

Adobe Dreamweaver adalah Suatu perangkat lunak web editor keluaran Adobe. Sistem yang digunakan untuk membangun dan mendesign suatu website dengan fiturfitur yang menarik dan memberi kemudahan dalam penggunaannya (Hayuningtyas,2015:161). Adobe Dreamweaver adalah aplikasi desain dan pengembangan web yang menyediakan editor WYSIWYG (What You See Is What You Get) visual (lebih dikenal sebagai Design View) dan kode editor dengan fitur standar seperti syntax highlighting, code completion dan code collapsing (Wahana Komputer,2013:2).

Dari pengertian diatas Penulis menyimpulkan bahwa Adobe Dreamweaver adalah software design yang digunakan untuk mendesain web agar website yang dibuat lebih menarik dan mudah digunakan oleh pengguna.

\subsection{Pengertian Database}

Database adalah kumpulan tabel walaupun lebih tepat dikatakan kumpulan objek karena yang terkandung di dalam database sebenarnya bukan hanya tabel, melainkan indeks, view, constraint dan trigger (Raharjo, 2016:521). Database adalah bagian penting dalam sistem aplikasi, seluruh fitur yang ada menggunkan database untuk melakukan fungsinya. perancangan database pada aplikasi meliputi perancangan database server. Database sever adalah database utama yang ada diserver (Safaat,2015:140).

Dari pengertian diatas Penulis menyimpulkan bahwa Database adalah sistem aplikasi yang dirancang agar dapat menjadi sebuah aplikasi untuk menyediakan sebuah informasi untuk pengguna.

\subsection{UML (Unified Modelling Language)}

UML (Unified Modeling Language) adalah sebuah bahasa yang telah menjadi standar dalam industri untuk visualisasi, merancang dan mendokumentasikan sistem lunak, yang menawarkan sebuah standar untuk merancang model sebuah sistem (Safaat,2015:33). UML (Unified Modeling Language) Memiliki beberapa diagram antara lain :

\section{Use Case Diagram}

Use Case Diagram merupakan sebuah gambaran fungsionalitas sebuah sistem. Sebuah use case merepresentasikan interaksi antara aktor dengan sistem.

\section{Class Diagram}

Class merupakan inti dari pengembangan dan desain berorientasi objek. Class menggambarkan keadaan (atribut/properti) suatu sistem, sekaligus menawarkan layanan untuk memanipulasi keadaan tersebut (metoda/fungsi).

\section{Activity Diagram}

Activity Diagram merupakan state diagram khusus, dimana sebagai besar state adalah action dan sebagian besar transisi di trigger oleh selesainya state sebelumnnya (internal processing). 


\section{METODE PENELITIAN}

\subsection{Metode Penelitian}

Metode penelitian adalah penelitian yang dilakukan untuk memperoleh data yang akurat (Hartini and Sarjono,2016:31).

\subsubsection{Teknik Pengumpulan Data}

Teknik pengumpulan data merupakan langkah yang paling strategis dalam penelitian, karena tujuan utama dari penelitian adalah mendapatkan data. Tanpa mengetahui teknik pengumpulan data, maka peneliti tidak akan mendapatkan data yang memenuhi standar data yang ditetapkan (Supriono,2015:3).

Dalam teknik pengumpulan data penulis menerapkan berbagai teknik pengumpulan data yang dilakukaan dengan cara :

\section{Pengamatan (Observasi)}

Yaitu pengumpulan data yang dilakukan Penulis dan mengamati langsung

Ke Koperasi Kartika Samara Grawira Prabumulih untuk mendaptakan data yang dibutuhkan.

2. Wawancara (Interview)

Yaitu pengumpulan data yang dilakukan dengan secara komunikasi dan tanya jawab langsung dengan Pimpinan, Bendahara dan Pegawai Koperasi Kartika Samara Grawira Prabumulih untuk dapat data sesuai kebutuhan Penulis.

\section{Studi Kepustakaan (Library Research)}

Yaitu pengumpulan data yang dilakuakan dengan membaca buku-buku, jurnal atau mengumpulkan sumber tertulis dengan cara membacar dan mencari referensi dari Penelitian.

\subsubsection{Sumber Data yang Penulis teliti}

Sumber data yang digunakan dalam penulisan Penelitian yaitu :

\section{Data Primer}

Merupakan data yang dikumpulkan secara langsung oleh penelitian dari objekobjek yang diteliti dalam Koperasi Kartika Samara Grawira Prabumulih.

\section{Data Sekunder}

Merupakan data pendukung inFormasi dari data primer yang diperoleh baik dari jurnal, buku bacaan dan internet.

\subsection{Analisis Sistem Berjalan}

\subsubsection{Analisa Dokumen}

Analisa dokumen merupakan penjelasan mengenai dokumen-dokumen yang digunakan dalam sistem Penjualan dan Pembelian Barang di Koperasi Kartika Samara Grawira Prabumulih.

\subsubsection{Analisis Prosedur Yang Sedang Berjalan.}

Analisis sistem yang sedang berjalan pada sistem Penjualan dan Pembelian Barang di Koperasi Kartika Samara Grawira Prabumulih. bertujuan untuk mengetahui lebih jelas bagaimana cara kerja sistem tersebut dan masalah yang di hadapi sistem tersebut untuk dapat dijadikan sistem yang baru agar terkomputer, perancangan analisis 
sistem yang sedang berjalan yang di lakukan berdasarkan urutan kejadian yang ada dan dari urutan kejadian tersebut dapat di deskripsikan sebagai berikut :

1. Anggota ataupu non anggota Koperasi Kartika Samara Grawira Prabumulih datang ke koperasi untuk membeli barang yang di inginkan.

2. Karyawan yang berkerja disana melayani calon pembeli, jika ada yang sudah membeli barang dikoperasi, karyawan disana langsung menulis nama barang serta harga barang yang sudah dibeli kedalam buku transaksi harian. Penulisan transaksi harian dibuku yang sama hanya dibedakan dengan warna tinta penulisannya saja, untuk pembelian secara tunai penulisannya menggunakan tinta berwarna hitam sedangkan pembelian secara kredit penulisannya menggunakan tinta berwarna merah. Pembelian secara kredit hanya diizinkan untuk anggota Koperasi dan anggota TNI saja.

3. Sebelum Koperasi ditutup karyawan membuka buku transaksi hariannya kembali untuk dilakukan pengecekan ulang untuk mengetahui barang apa saja yang sudah terjual, mengetahui berapa pemasukan dalam perharinya, membuat catatan sementara untuk anggota koperasi dan anggota TNI yang melakukan transkasi secara kredit. Setelah itu buku transaksi harian yang sudah direkap oleh karyawan koperasi langsung diberikan ke bendahara koperasi.

4. Setiap tanggal 11 sebelum koperasi dibuka semua karyawan dan petugas melakukan pengecekan barang di dalam koperasi untuk mengetahui stok sisa barang di Koperasi Kartika Samara Grawira Prabumulih.

5. Setiap bulannya pada tanggal 27 sampai 29 karyawan dan bendahara berkerja sama untuk mengelolah data nama-nama anggota TNI yang masih memiliki hutang untuk dibuat laporan kekantor agar setiap anggota TNI yang memiliki hutang bisa dipotong dengan pendapatan perbulannya.

\section{HASIL DAN PEMBAHASAN PENELITIAN}

\subsection{Hasil}

Aplikasi perangkat lunak yang dihasilkan dalam Penelitian di implementasikan untuk Aplikasi Penjualan dan Pembelian pada Koperasi Kartika Samara Grawira Prabumulih. Menggunakan Bahasa Pemograman PHP dengan database yang digunakan adalah Mysql dan menggunakan program pendukung lainnya yaitu Macromedia Dreamweaver dan xampp. Aplikasi perangkat lunak yang dihasilkan terdiri dari 8 buah Form. Form itu antara lain Form login, Form password admin, Form data provinsi, Form data kategori, Form data barang, Form data pelanggan, Form data pemesanan barang, Form konfirmasi transfer, Form hubungi, dan Form laporan. Form Laporan - laporan yang terdiri dari laporan data provinsi, laporan data kategori, laporan data barang,laporan data pelanggan, laporan pemesanan masukperiode, laporan pemesanan lunas-tanggal dan laporan pemesanan lunas-periode.

\subsection{Pembahasan}

Menjalankan Aplikasi Penjualan dan pembelian barang di Koperasi Kartika Samara Grawira Prabumulih dilakukan dengan berbagai cara sebagai berikut : 
1. Nyalakan komputer anda, tunggu komputer menampilkan area kerja (Desktop) Windows.

2. Tekan Star, Klik All Program, Klik Program Xampp untuk mengkonekasi kan ke Apache, MySql, FileZilla klik Star untuk menjalankan Xampp

3. Tekan atau klik Browser Google Chrome, Mozila atau Internet Explorer.

4. Isikan alamat pada url aplikasi browser kita yaitu dan alamat http://localhost/koperasi/

5. Tekan Enter dan akan muncul ke halaman website aplikasi penjualan dan pembelian barang pada Koperasi Kartika Samara Grawira Prabumulih..

6. Silakanan Isikan Pendaftaran Baru lalu isi username dan password yang telah terdaftar untuk dapat mengakses website aplikasi penjualan dan pembelian barang pada Koperasi Kartika Samara Grawira Prabumulih.

\section{KESIMPULAN DAN SARAN}

\subsection{Kesimpulan}

Kesimpulan yang diambil dari perancangan dan implementasi rancang bangun aplikasi penjualan dan pembelian barang pada koperasi kartika samara grawira prabumulih adalah :

1. Rancang Bangun Aplikasi Penjualan dan Pembelian barang pada Koperasi Kartika Samara Grawira Prabumulih mengunakan Bahasa Pemograman PHP ( Hypertext Preprocessor ) dan menggunakan sistem database MYSQL untuk mempermudah dalam pembuatan Aplikasi Penjualan dan Pembelian barang pada Koperasi Kartika Samara Grawira Prabumulih yang terdiri dari tabel admin, tabel provinsi, tabel kategori, tabel barang, tabel pelanggan, tabel transasksi pemesanan, tabel pemesanan_item, tabel keranjang belanja, tabel data konfirmasi, tabel hubungi.

2. Aplikasi Penjualan dan Pembelian Barang di Koperasi Kartika Samara Grawira Prabumulih berbasis website ini bertujuan untuk mempermudah kerja Pegawai untuk melakukan transaksi penjualan maupun pembelian.

3. Dengan Aplikasi ini Penjualan tidak hanya dilakukan di Koperasi saja dan mampu memasarkan barang-barang secara luas.

\subsection{Saran}

Berdasarkan peneitian dan perancangan sistem yang penulis lakukan di koperasi kartika samara grawira prabumulih, ada beberapa saran yang ingin penulis kemukakan, diantaranya adalah:

1. Perlu adanya kerja sama antara koperasi dengan agen pengiriman, agar pengiriman barang dapat lebih mudah dalam pengecekannya.

2. Perlu adanya pengembangan pada desain tampilan agar lebih menarik sehingga dapat lebih banyak memikat minat pelanggan dan perlunya pelatihan terhadap admin yang akan mengelola website.

3. Perlu adanya penambahan fasilitas lain yang mendukung fungsionalitas website sehingga konsumen akan terus mengunjungi website dengan kata lain jika sering masuk website maka kemungkinan untuk berbelanja pun semakin meningkat. 


\section{DAFTAR PUSTAKA}

Agustina Lela and Dr. Parjono, M.Si, 2017. Pengaruh Suasana Toko dan Keanekaragaman Produk Terhadap Kepuasan Pembeli pada Konsumen Toserba Maya di Kec.Randublatung Kab. Blora. "Jurnal Pendidikan Tata Niaga (JPTN) ", ISSN: 2337-6708 Vol. 01 No.01 : 39-43.

Fathurrahman, 2014. Membuat Website Mudah dan Praktis dengan Weeble, Jakarta : Penerbit PT Elex Media Komputindo.

Fatkhudin, Aslam, 2016. Sistem Informasi Penjualan dan Pembelian pada Toko Elektronik Lubada Jaya Kajen dengan Menggunakan Java. Pekalongan."Jurnal DIGITAL", ISSN : 2088-589X Vol.6 No.1 : 23-36.

Hariyanto Dicky, 2016. Rancang Bangun Sistem Informasi Pembelian dan Penjualan Barang Berbasis Website. "Jurnal dari SWABUMI “, ISSN : 2355-990, Vol. IV No. $2: 152-166$.

Hartini Dwi and Sarjono, 2016. Analisis dan Perancangan Sistem Informasi Penjualan pada PT.Jaya Mandiri Strategic. Jambi. "Jurnal Manajemen Sistem Informasi", ISSN : 2540-8011 Vol.1 No. $1: 30-34$.

Hasyim Nurlaila, Nur Aeni Hidayah, Sarwoto Wijoyo Latisuro, 2014. Rancang Bangun Sistem Informasi Koperasi Berbasis Web pada Koperasi Warga Baru MTS N 17. Jakarta. “Jurnal dari Sistem Informasi”, ISSN 1979-0767. 7(2) : 1-11.

Hayuningtyas Ratih Yulia, 2015. Rancang Bangun Sistem Informasi Penjualan Tas pada Toko Lokalop. "Jurnal dari Sistem Informasi STMIK antar Bangsa", ISSN 2089- 8711 Vol. IV NO.2 : 160-167.

Hendar S.E., M.Si, 2010. Manajemen Perusahaan Koperasi. Jakarta : Penerbit Erlangga.

Maulana Kiki Rizki and Bunyamin, 2015. Rancang Bangun Aplikasi Sistem Informasi Penjualan dan Stok Barang di Toko Widari Garut. "Jurnal Algoritma”, ISSN : 2302-7339 Vol. 12 No. $1: 1-6$.

Mega, Mahar, 2013. Manajemen Pemasaran. Yogyakarta : CAPS (Center of Academic Publishing Service).

Nugroho, Bunafit, 2013, Membuat Aplikasi WEB Penjualan Pembelian dengan PHP, MySQL dan Dreamweaver. Yogyakarta : Penerbit PT.Alif Media.

Raharjo, Budi, 2015. Belajar Otodidak MySQL. Bandung : penerbit informatika Bandung.

Raharjo, Budi, 2016. Pemrograman Web (HTML, PHP, \& MySQL) edisi ketiga. Bandung : penerbit Modula.

Riyono and Gigih Erlik Budiharja, 2016. Pengaruh Kualitas Produk, harga, Promosi dan Brand Image terhadap Keputusan Pembelian Produk di Kota Pati. "Junal Stie Semarang”, ISSN : 2252-826 Vol 8 No 2 : 92-121.

Rudianto, 2010. Akuntansi Koperasi Konsep dan Teknik Penyusunan Laporan Keuangan Edisi Kedua. Jakarta : Penerbit Erlangga.

Rumanta, 2013. Perancangan Sistem Informasi Pembelian dan Penjualan pada Oka Putra Motor Pacitan. “Jurnal Seruni”, ISSN : 2302-1136 Vol 2 No 1 : 44-49.

Safaat Nazruddin H, 2015. Rancang Bangun Aplikasi Multiplatform, Bandung : Penerbit Informatika Bandung.

Sandi, Mulyana, 2014. Bikin Website dengan Aplikasi-aplikasi Gratis, Yogyakarta : Penerbit PT.Buku Seru. 
Supardi Yuniar, 2015. Mudah dan Cepat Membuat Skripsi dengan VB 2012, Jakarta : Penerbit PT Elex Media Komputindo.

Tim EMS, 2014. Teori dan Praktek PHP-MySQL untuk Pemula, Jakarta : Penerbit PT. Elex Media Komputindo.

Wahana Komputer,2013. Mobile Web Devolopment with Adobe Dreamweaver CS6. Semarang : Penerbit C.V ANDI Offset.

Zulfiandri, Sarip Hidayatuloh and Mochammad Anas, 2014. Rancang Bangun Aplikasi Poliklinik Gigi. "Prosiding Seminar Ilmiah Nasional Komputer dan Sistem Intelijen", ISSN : 2302-3740, Vol. 8 : 472-482. 